\title{
ECOLOGY
}

\section{ПРОБЛЕМИ ЗАБРУДНЕННЯ ВОДНИХ РЕСУРСІВ. ЕКОЛОГІЧНИЙ АСПЕКТ.}

\author{
${ }^{1}$ Захарова С. О., кандидат філософських наук, дочент \\ ${ }^{2}$ Архіпова К. К., старший викладач \\ ${ }^{1}$ Кафедра будівництва та ичиільної інженерії, Запорізький інститут економіки та \\ інформаційних технологій, м. Запоріжжя, Украйна \\ ${ }^{2}$ Кафедра міського будівництва та господарства, Запорізька державна інженерна академія \\ м. Запоріжжя, Україна
}

\section{DOI: https://doi.org/10.31435/rsglobal_ws/30082018/6068}

\begin{tabular}{|c|c|}
\hline ARTICLE INFO & ABSTRACT \\
\hline $\begin{array}{l}\text { Received: } 24 \text { July } 2018 \\
\text { Accepted: } 11 \text { August } 2018 \\
\text { Published: } 30 \text { August } 2018\end{array}$ & \multirow{3}{*}{$\begin{array}{l}\text { In the context of global crises generated by the technogenic civilization, } \\
\text { and, above all, modern ecological crises, the most important today is the } \\
\text { issue of further development of human activity, which will, firstly, be } \\
\text { aimed at preventing a global ecological catastrophe, preserving the } \\
\text { balance of modern civilization with its modified nature, and secondly, } \\
\text { the cardinal measures to correct the existing ecological situation. } \\
\text { The article deals with innovative directions of sewage treatment, the } \\
\text { principles of a closed cycle of water resources use, the status of water } \\
\text { objects in Ukraine and, partly, in the Zaporozhye region. Ukraine, along } \\
\text { with the developed countries of the world, is on the way to ecologization } \\
\text { of life. The measures taken and those decisions that take time to } \\
\text { implement them are aimed at achieving non-waste processes in industry } \\
\text { and utilities, the application of innovative technologies for the } \\
\text { purification and recycling of human waste, in particular sewage. }\end{array}$} \\
\hline KEYWORDS & \\
\hline $\begin{array}{l}\text { Ecological situation, } \\
\text { water resources, } \\
\text { sewage, } \\
\text { innovative technologies, } \\
\text { alternative types of energy, } \\
\text { ways of ecologization. }\end{array}$ & \\
\hline
\end{tabular}

Citation: Захарова С. О., Архіпова К. К. (2018) Problemy Zabrudnennia Vodnykh Resursiv. Ekolohichnyi Aspekt. World Science. 8(36), Vol.2. doi: 10.31435/rsglobal_ws/30082018/6068

Copyright: (C) 2018 Захарова С. О., Архіпова К. К. This is an open-access article distributed under the terms of the Creative Commons Attribution License (CC BY). The use, distribution or reproduction in other forums is permitted, provided the original author(s) or licensor are credited and that the original publication in this journal is cited, in accordance with accepted academic practice. No use, distribution or reproduction is permitted which does not comply with these terms.

Вступ. Людство вже кілька десятиліть балансує на межі екологічної катастрофи. Друга природа, що створювалася людством штучно на протязі тисячоліть, вступила в небезпечний конфлікт перетворення. Природа, що дає людству все, від повітря, води і їжі до корисних копалин і джерела енергії, забруднюється і знищується відходами людського існування i діяльності, утилізація яких здійснюється у природі. Розглянемо тільки один 3 аспектів життєдіяльності людини - забруднення водних ресурсів.

Вода - джерело життя всіх організмів, початок людської цивілізації. Вода забезпечує усі сфери життя і діяльності людини. Частка прісної води планети, що придатна задовольнити людські потреби, становить всього 0,3\% гідросфери. Згідно зі статистичними даними щорічно в ріки, моря й озера світу скидається до 400 млрд. кубометрів стічних вод. Тобто, 5,5 тисяч мільярдів кубометрів води на планеті знаходитися в забрудненому стані. Це більш 14\% від загального обсягу водних ресурсів світу.

За даними ООН про стан водних ресурсів світу (доповідь на конференції 2018 року):

- 1,8 млрд. людей користуються незахищеними джерелами питної води, зокрема від фекального забруднення; 
- понад 80 \% стічних вод, що скидаються в навколишнє середовище не проходить очищення. В країнах з високим рівнем доходів ця цифра сягає 70\%, у країнах з низьким рівнем доходів-лише $8 \%$.

Джерелом забруднення води $є$ побутові і промислові стічні води, не очищені від синтетичних, хімічних елементів і органічних речовин; кислотні дощі на основі викидів промислових підприємств, автомобільного транспорту; тверді відходи; органічні забруднення, пов'язані з діяльністю людини, розкладанням померлих тварин, рослин; аварії і катастрофи; виділення теплапри виробництві електричної енергії.

Міжнародні експерти Всесвітньої організації охорони здоров’я (ВООЗ) стверджують, що причиною майже 60\% людських захворювань зумовлено є вживання недоброякісної води.

Таким чином, можна констатувати, що:

- Рівень забезпеченості людства водою для питних, битових та промислових потреб дуже низький, і з кожним роком, у зв’язку з техногенним розвитком, зі збільшенням кількості жителів планети, погіршується.

- Стан існуючих водних ресурсів дозволяє користуватися водою тільки після належного очищення, можливо новими методами, що потребує серйозних інвестицій.

- Стічні води, що потрапляють у водні ресурси, часто без очищення, призводять до замулювання рік та інших водних поверхонь, хімічного і біологічного забруднення, порушення стійкості екосистем і всього харчового ланцюга.

- Для людини споживання неочищеної води загрожують цілою низкою захворювань, від захворювання системи травлення до захворювань, що в змозі змінити структуру ДНК; онкологічні; захворювання, що можуть провокувати уповільнення реакції мозку, руйнування нервових кліток, здатні змінювати енергетичні процеси в організмі, а також визивати репродуктивну недостатність.

Отже, однією 3 найважливіших умов подальшого існування людства, його повноцінного життя і діяльності є вирішення екологічної проблеми забруднення світового запасу прісних від.

Результати дослідження. Стан світових водних ресурсів досліджується комісією ООН щорічно. У доповіді Організації Об'єднаних Націй про стан водних ресурсів світу, під назвою «Стічні води: невикористаний потенціал» 2017 року зазначено, що стічні води є коштовним ресурсом, оскільки світові запаси доступної прісної води обмежені, у той час як попит на неї росте. Завдання кожного - розробити свій внесок у досягнення мети стійкого розвитку по скороченню наполовину кількості неочищених стічних вод і збільшенню їхнього безпечного повторного використання до 2030 року [1]. Головною ідеєю названо такі екологічні методи очищення стічних вод, що надають можливість для іiі повторного використання, а побічні продукти можуть стати безцінним ресурсом для випуску електроенергії і добрив, що вирішує аспекти утилізації відходів. Наголошується, що удосконалювання відведення й очищення стічних вод припускає не тільки зниження кількості відходів на місці їхнього утворення, але й очищення стічних вод від забруднюючих речовин, повторне використання очищеної води [1].

У всесвітній доповіді Організації Об'єднаних Націй про стан водних ресурсів 2018 року продовжено тему пошуку екологічних рішень у сфері водних ресурсів і названо задачі, що вирішуються за допомогою «природних рішень (ПР)»: стійкий розвиток сільського господарства, забезпечення здорового способу життя, створення стійкої інфраструктури (пов'язаної з водними ресурсами), забезпечення екологічної стійкості міст і населених пунктів і зменшення небезпеки катастроф, питання зміни клімату [2].

Питання інтенсифікації очищення стічних вод розглянуто в роботах ряду вчених: Яковлева С.В., Воронова Ю.В., Синева О.П., Каліцуна В.І., Кулікова М.І., Гвоздяка П.І., Нездоймінова B.I., Епояна С.М., Ткачука Н.Г. і ін.

Проблемою утворення та утилізації осадів стічних вод займались: Дрозд Г.Я., Веремеєнко C.I., Кучерова А.В. Гіроль А.М., Дишлюк В.С., Вербовський О.В., Качан Х.П., Снітинський В.В., Черниш Є. Ю., Пляцук Л.Д. та інші.

Питання впливу забрудненої води на організм людини розглядалася такими вченими, як Л.В. Дичка, А.В. Фединяк, Н.В. Флекей, Л.С. Григоренко, питання екологічних проектів в Україні освічував М.М. Олексієнко.

За оцінкою вітчизняних експертів, Україна є однією з найменш забезпечених у Свропі країн за запасами місцевих водних ресурсів - 1 тис. куб. м на 1 жителя (у Швеції та Німеччині 2,5 тис. куб. м на 1 жителя, Франції - 3,5, Великобританії - 5). Фахівцями Національного інституту стратегічних досліджень зазначено, що неефективне та безкарне використання 
водних ресурсів України, зокрема ріки Дніпро, призвело до техногенних порушень, за індексом екологічної ефективності Україна зайняла у 2018 році 109 місце із 180 країн [3]. Виправленню ж ситуації заважає низький рівень екологічної політики в Україні, відсутність уваги до реформ у сфері навколишнього середовища.

Водні об’єкти України вкривають 24,2 тис.кв.км, що становить 4,0\% від іiї загальної території (603,7 тис. кв. км). У більшості міст України водопостачання здійснюється 3 поверхневих джерел, частка води з артезіанських свердловин - мізерна. Основним джерелом водопостачання міста Запоріжжя і Запорізької області на 95,7 \% є р. Дніпро [8].

Водночас, за узагальненими даними державного обліку водокористування у 2017 році Запорізька область займала третє місто в Україні, після Дніпропетровської та Донецької області, за кількістю скидів забруднених стічних вод. Запоріжжя, що є великим промисловим містом здійснює забір води для забезпечення виробничих потреб великих промислових підприємств, зокрема ПАТ «Запоріжсталь», ВП «Запорізька ТЕС» ПАТ «ДТЕК Дніпроенерго», ВП «Запорізька АЕС», ДП НАЕК «Енергоатом», АТ «Мотор Січ», а також для потреб зрошення. Найбільша кількість забруднених вод скидається підприємствами чорної i кольорової металургії та житлово-комунальним сектором. У Регіональній доповіді про стан навколишнього природного середовища в Запорізькій області зазначено, що на території Запорізької області нараховується 177 одиниць очисних споруд, у тому числі: механічної очистки - 77, біологічної очистки - 55, фізико - хімічної очистки - 45. Якість очистки стічних вод на багатьох 3 них не відповідає нормативним вимогам діючого природоохоронного законодавства України та не дозволяє повторно використовувати очищені стічні води у виробництві [4].

Між тим, на світовому рівні в останні роки діяльність в галузі ресурсозберігаючих і природоохоронних технологій стала однієї з перспективних і прибуткових. Наприклад, Америка займає 4-е місце в світі за річним оборотом капіталу у галузі керування відходами. У країнах ЄС темпи росту в цій сфері економіки щорічно складають $20 \%$, їхнє зростання очікується до 50\%. Реалізація концепції «поділу й утилізації» сприяє не тільки рішенню екологічних проблем, але і дозволяє отримати прибуток [7].

Одним з перспективних напрямків переробки осадів стічних вод $€$ термічне розкладання 3 метою одержання біопалива. В Китаї, наприклад, працює біля 10 млн установок 3 виробництва біогазу, що забезпечує на 60-80\% громадський транспорт країни [5]. В Європі біогаз використовують як паливо для ТЕЦ для забезпечення електроенергією міст, для забезпечення газовим паливом міського транспорту, для використання біогазу у газових мережах країн. Щорічно підвищення видобутку біогазу в ЄС досягає $25 \%$, при цьому $57 \%$ видобутку припадає на біогаз, що є продуктом очищення стічних вод [6].

Сировиною для виробництва біогазу також може слугувати будь-який біологічний агропродукт. Україна має значний потенціал таких біологічних ресурсів. На території України накопичено близько 5 млрд. т комунальних відходів. Для їхнього розміщення з господарського обороту вилучено більш 10 тис. га землі [7]. При належній переробці осади можна застосовувати для вирощування розсади овочів, в зелено-парковому господарстві, квітництві, садівництві, у приватних господарствах. Встановлено, що в Україні не менш $30 \%$ накопичених опадів (17 млн. т) може бути використане в сільському господарстві. За даними Запорізької державної сільськогосподарської дослідної станції, внесення сухого осаду стічних вод у грунт у кількості 30 т/га при вирощуванні зеленої маси люцерни дає збільшення до врожаю $27 \%$, а гною в кількості 50 т/га - 24\%, що свідчить про ефективність використання осаду як добрива.

Так, у Люксембурзі як добрива використовується 90\% осадів стічних вод, у Швейцарії$70 \%$, у Данії - 54\%, Франції - 30\%, Голландії - 25\%. Продукти переробки твердих осадів також спрямовуються на виробництво будівельних матеріалів, при будівництві доріг, або як матеріали для рекультивації полігонів поховання твердих побутових і промислових відходів при наявності в осадах важких металів.

У Данії, компанією Danfoss Power Electronics розроблено нову технологію очистки стічних вод, що дозволяє отримати чисту питну воду високої якості, а також енергію, що не тільки забезпечує діяльність очисних споруд, але й дає ії надлишок, який можна продавати в мережі. За допомогою цієї технології енергія генерується 3 біогазу, що отримують 3 каналізаційних відходів в автоклавах.

Очищені стічні комунальні води на повторному циклі використання можуть спрямовуватися на зрошення сільськогосподарських земель, на полив зелених міських насаджень, у ставках для вирощування риби. 
Використовуючи органічні осади тваринницьких підприємств, м'ясомолочної промисловості, а так само осади станцій очищення побутових стічних вод в Україні можна виробляти 54 млн. м ${ }^{3}$ біогазу щорічно, що дозволить замінити 24 тис.т. бензину [5]. На очисних спорудах м. Запоріжжя з продуктивністю 1 млн. куб. м за добу можливо одержати 15 млн. куб. м природного газу.

Висновки. Україна має величезний потенціал вироблення енергії з альтернативних джерел. Розвиток галузі виробництва біогазу і біопалива надає можливості одночасно підвищити рівень екологічної безпеки, утилізуючи органічні відходи, а також скоротити кількість шкідливих викидів, відповідно до вимог Кіотського протоколу. Для стимулювання розвитку видобутку з альтернативних джерел енергії, у 2015 р. розроблено Закон України «Про внесення змін до деяких законів України щодо забезпечення конкурентних умов виробництва електроенергії з альтернативних джерел енергії» [11]. Також Законом України «Про внесення змін до Закону України «Про теплопостачання» щодо стимулювання виробництва теплової енергії з альтернативних джерел енергії» [12] запроваджено стимулюючий тариф на тепло, вироблене 3 біогазу. Відповідно до міжнародних рішень, Україною розроблено і ухвалено документ «Проект закону України про стратегію сталого розвитку України до 2030 року», одним 3 напрямків якого $є$ підвищення якості природних вод шляхом зменшення скидів забруднюючих речовин і матеріалів та скорочення обсягів забруднених стічних вод до 5\% (від загального обсягу водовідведення), зокрема шляхом стимулювання будівництва нових, реконструкції та модернізації діючих очисних споруд.

Отже, кроки у напрямку екологізації процесів життєдіяльності населення України вже зроблено. Країна має стислі часові межі на здійснення цих рішень. На відміну від країн Європи, Японії, Америки, які здійснювали аналогічні кроки і зміни 30-40 років, Україна повинна пройти шлях свідомої екологізації за 10-12 років.

Найважливішими напрямками ми вважаємо:

- обов'язкову реконструкцію діючих підприємств із застосуванням інноваційних прибуткових методів переробки стічних вод і відходів життєдіяльності людини, перехід на економіку замкнутого циклу, коли основним завданням $€$ перетворення відходів на ресурси і їх повторне використання; спрямування пільгових кредитів i регресивного оподаткування підприємствам по програмам скорочення шкідливих викидів та переробки відходів;

- створення відкритої інформаційної платформи щодо обізнаності населення на всіх рівнях, від представників влади до пересічних громадян, про реальний екологічний стан країни; поінформованість і знання про необхідність і реальні переваги ПР; оприлюднення достовірної інформації щодо якості питної води, повітря, продуктів харчування; звіти діючих підприємств щодо стану очисних споруд, кількості викидів і прогнозування їхнього впливу на екологічний стан навколишнього середовища і на здоров’я населення;

- посилення принципів екологічного виховання дітей і молоді в навчальних закладах, подолання байдужого відношення населення до екологічних наслідків життєдіяльності кожного;

• забезпечення прав кожної людини на використання чистої питної води і чистого повітря.

\section{ЛІТЕРАТУРА}

1. 2017 UN World Water Development Report, Wastewater: The Untapped Resource. URL: http://www.unesco.org/new/en/natural sciences/environment/water/wwap/wwdr/2017-wastewater-theuntapped-resource/

2. 2018 UN World Water Development Report, Nature-based Solutionsfor Water. URL: http://www.unesco.org/new/en/natural-sciences/environment/water/wwap/wwdr/2018-nature-basedsolutions/regional launches/

3. Environmental Performance Index 2018 (EPI). URL: https://epi.envirocenter.yale.edu/sites/default/files/2018-ukr.pdf

4. Regionalna dopovid pro stan navkolychnjogo pryrodnogo seredovycha v Zaporizkiy oblasti v 2016 rotsi. ZODA, Depertament ecologii I pryrodnyh resursiv. Zaporijya, 2017.

5. Kaletnik G.M. Biopalyvo. Prodovolcha, energetychna ta ecologichna bezpeka Ukrainy. (2010). Kaletnik G.M. Kyiv. Haj-Tek Press.

6. Klimchuk O.V., Groh N.V. Vyrobnitstvo biogazu dosvid zarubijnyh krain ta perspektyva rozvytky v Ukraini. Zbirnyk naukovyh prats VNAY. Vinnytsya, 2012. №2 (64). C 50-54.

7. Dolyna L.F. The sediment of the waste and drinking waters: problems and decisive. (2014). Dolina L. F., Machihina P.B. Dneproretrovsk: Kontinent [in Ukrainian]. 
8. Ofitsiynyj sajt Ministerstva ecologii ta pryrodnyh resursiv Ukrainy [Electronnyj resurs]. URL: http://www.menr.gov.ua/

9. Natsionalna dopovid «Tsili stalogo rozvytku: Ukraina» 2017. URL :http://un.org.ua/ua/publikatsii-tazvity/un-in-ukraine-publications/4203-2017-natsionalna-dopovid-tsili-staloho-rozvytku-ukraina-iakavyznachaie-bazovi-pokaznyky-dlia-dosiahnennia-tsilei-staloho-rozvytku-tssr

10. Proect zakonu Ukrainy vid 07.08.2018 r. Pro strategiju stalogo rozvytku Ukrainy do 2030 roku. URL http://search.ligazakon.ua/l_doc2.nsf/link1/JH6YF00I.html

11. Zakon Ukrainy «Pro vnesenja zmin do dejakyh zakoniv Ukrainy chodo zabezpechenja konkurentnyh umov vyrobnitstva electroenergii z alternatyvnyh dgerel energii» vid 4.06.2015 r. № 514-VIII // Vidomosti Verhovnoji Rady Ukrainy (VVR), 2015, № 33, ст. 324. URL http://zakon3.rada.gov.ua/laws/show/514-19

12. Zakon Ukrainy Pro vnesenja zmin do zakonu Ukrainy «Pro teplopostachannja» chodo stymuljuvannja vyrobnytstva teplovoi energii http://zakon.rada.gov.ua/laws/show/1959-19

z alternatyvnyh dgerel energii

URL 